\title{
The Importance of Learning Styles for higher secondary school students
}

\author{
Prabha Kiran Toppo', Dr. Fr. Ignatius Topno² \\ ${ }^{1}$ Research Scholar School of Educational Training and Research, Aryabhatta Knowledge University, \\ Patna, Bihar - 800011 \\ ${ }^{2}$ Professor (Principal), St. Xavier's College of Education (Autonomous), Patna, Bihar - 800011
}

\begin{abstract}
In the field of education recent advancement and issues have deeply affected the learning of students. They are confronted and challenged to possess different types of learning styles. Learning style is a form of human behaviour that individuals use for new learning. Therefore, learning styles are widely accepted by the learners to face the learning problems. Each student has the natural way of learning to learn best. The way by which students approach their learning tasks and behavior determines the learning styles. Students solve their problems of learning with different learning styles. In this study learning styles include visual, aural, verbal, kinesthetic, logical, social or interpersonal, solitary or intrapersonal learning. Leaning styles help them to learn new and difficult information to compete. It prepares them for future life. To study the importance of learning styles of higher secondary school students' researcher has considered survey method. The researcher has used self made tool on learning styles for data collection. The sample consisted of 239 higher secondary school students of Ranchi District. To analyze data Mean, SD and ' $t$ ' test were used. The finding of the study showed that there is no significant differences in the learning styles of higher secondary school students on the basis of gender (male and female), types of school (government and private), habitation (rural and urban) and residence (day scholar and hosteller). The study is concluded that higher secondary schools students were found similar in respect of their learning styles. Yet, it can be said that learning style is important for the students for their future life.
\end{abstract}

Key words: Learning Styles and higher secondary.

\section{INTRODUCTION}

At this present juncture students are challenged due to their learning capabilities. Current issues and environment, cognitive and emotional factors are also affecting the learners learning. The world has changed and has become very competitive hence each individual needs to excel in every area of life. To fulfill the demand of time all are trying to encounter the challenges of learning. We all know that each person has unique and different learning preferences therefore students differ in the ways of learning. Learning is a fundamental need for every individual to progress. The researcher has taken seven learning styles for the study they are visual, aural, verbal, kinesthetic, logical, interpersonal and intrapersonal learning. It brings tremendous change in students. By using different learning styles students can learn best and improve their learning.

\section{LEARNING STYLES}

In the process of learning an individual needs to acquire his/her own learning style. Learners are responsible to search their learning problem and to explore their own learning styles. In this study learning styles comprise of visual, aural, verbal, kinesthetic, logical, social or interpersonal, solitary or intrapersonal learning. Learner needs to know what is their learning styles, how to learn and how to solve their learning problems. The awareness will bring tremendous change in learner's learning. The knowledge of learning style is important for all the students for many reasons. Firstly, each individual is different from one another therefore, learning style varies. Secondly, teachers may use different methods in an effective way to teach students according to their learning styles. Thirdly, identifications of students learning styles can help the teacher to manage the things in education and teaching learning process can be regulated to the desirable direction.

Each individual has its own way or style to acquire and process information. There are various ways through which an individual learns like learning by seeing, hearing, working alone or in a group, reasoning logically and intuitively, by memorizing or visualizing. These common ways of learning are known as learning styles. We all are unique in our learning styles and each style has its own advantages. Learning styles are the helpful means which allows individual to learn best. It is an innate preference of individuals in learning information. This style helps individuals to concentrate, process, internalize and retain new and difficult information. According to Keefe (1979), learning style is defined as a 


\section{International Advanced Research Journal in Science, Engineering and Technology \\ Impact Factor $7.105 \div$ Vol. 9, Issue 1, January 2022 \\ DOI: 10.17148/IARJSET.2022.9153}

set of cognitive, emotional, characteristic and psychological factor by which learner perceives, interacts with and responds to the learning environment.

\section{REVIEW OF RELATED LITERATURE}

The review of the related literature unfolds the student's learning styles which plays an important role in their academic success. Gopalakrishnan and Palanivelu (2018) revealed that kinesthetic learning style is more popular in visual and auditory learning styles. Anand and Prasad (2016) showed that maximum students who adopted visual, audio, kinesthetic learning styles were better in their classroom learning. Mallick and et.al (2016) revealed that rural and urban boys and girls differ in their independent, dedicated, collaborative, competitive and participative learning styles. Bhagat and et.al (2015) analyzed that awareness in learning styles of students motivated them to adopt mixed methods for learning. Rai and Khatri (2015) examined learning styles among undergraduate students. The result showed that $41.66 \%$ students preferred unimodal learning style, 58.34\% students preferred multimodal learning style and $33.33 \%$ students preferred kinesthetic learning style. On the other hand Kharb and et.al (2013) narrated that $61 \%$ students preferred multimodal VARK preferences and among them $41 \%, 14 \%$ and $6 \%$ preferred sequentially bimodal, trimodal and quadrimodal. 39\% respondents had only one strong learning preference. The most common preferences of the students were kinesthetic, visual, auditory, read and write etc. The maximum preferred teaching methodology was $39 \%$ and tutorial was preferred minimum only 12\%. Singh and et.al (2015) explored a study to find out the relationship between preferred learning styles among secondary school students in their fender, place of living, religion and education level of parents. Findings showed the percentage of preferred learning styles in students' visual learners were $45.7 \%$, auditory learners were $(21 \%)$, tactile learners were $18.3 \%$ and kinesthetic learners were $15 \%$. It also revealed no significant impact on gender, place, religion and education level of parents. Singh and et.al. (2015) revealed no significant impact of gender, place of living, religion and educational level of father's learning style preferences but found significant impact of mothers' educational level. The study provided better understanding to the teachers in framing curriculum, lesson planning and teaching students according to their learning styles. Learning styles are important not only in shaping students but it also helps policy makers, administrators, curriculum framers, stakeholders, parents and teachers to think deeply about their role in facilitating. Bhat and Govil (2014) investigated the preferred learning style of secondary students and its role in academic performance. This study explored to find out the differences in learning styles in relation to gender, residential background and type of institution. For data collection Kolb's (1999) learning style inventory (LSI) was used. To measure the relationship between learning style and academic achievement prior marks were used. The result revealed that largest number of the students liked accommodator and assimilator learning styles. The analysis showed that learning style influences academic success of students. It also revealed that demographic variables are not affected but type of institution was significantly affected. Hemalatha (2013) revealed that in common all the college students were motivated to possess imaginative and dynamic learning styles. Result showed that only chemistry students adopted analytical and commonsense learning styles. It was concluded that learned practical skills are beneficial for day-to-day life of the students. Vaishnav (2013) revealed the kinesthetic learning style was popular than visual and auditory learning style but for the academic achievement visual, auditory and kinesthetic learning styles are helpful. Akhtar (2011) found that in classroom learning female students' opted different learning styles and students of private institution liked competitive learning style whereas students of public institution preferred avoiding learning style.

Hawkar Akram Awla. Learning Styles and Their Relation to Teaching Styles. International Journal of Language and Linguistics.

Vol. 2, No. 3, 2014, pp. 241-245. doi: 10.))11648/j.ijll.20140203.23

\section{SIGNIFICANCE OF THE STUDY}

Present world has become very competitive where an individual needs different types of knowledge to face the demand of the world. To acquire various types of knowledge students need to be fit in more than one learning styles. Multi learning styles will help the students to gather the various types of knowledge. It has been noticed that some of the students possess more than two learning styles which enables them to learn difficult topics. Present study will animate students to possess more than one learning styles to gather divergent knowledge, to achieve success in academic performance, to get success in competitive exam and to face the realities of life.

\section{OBJECTIVES}

1. To identify the importance of preferred learning styles of students with respect to gender.

2. To identify the importance of learning styles of students with respect to type of schools.

3. To identify the preferred learning styles of the students with respect to habitation. 


\section{International Advanced Research Journal in Science, Engineering and Technology \\ Impact Factor 7.105 ㄷ Vol. 9, Issue 1, January 2022 \\ DOI: $10.17148 / I A R J S E T .2022 .9153$}

4. To identify the importance of learning styles of students with respect to residence.

\section{Null Hypothesis}

1. There is no significant difference between preferred learning styles with respect to boys and girls of higher secondary school students.

2. There is no significant difference between preferred learning styles with respect to government and private higher secondary school students.

3. There is no significant difference between preferred learning styles with respect to rural and urban higher secondary school students.

4. There is no significant difference between preferred learning styles with respect to hosteller and day scholar higher secondary school students.

5 .

The population of the study

In the present study a sample of 238 higher secondary school students of Ranchi was selected from the population.

Method

The researcher has used survey method.

Tool used in the present study

To test the preferred learning style of higher secondary school students a self constructed and validated tool was used.

Statistical Techniques

For analyzing data researcher has used Mean, SD and ' $t$ ' test.

Hypothesis Testing

Table - 1: There is no significant difference between preferred learning styles with respect to boys and girls of higher secondary school students.

\begin{tabular}{|l|l|l|l|l|l|}
\hline & Mean & SD & t-value & Result & $\begin{array}{l}\text { Level of } \\
\text { Significance }\end{array}$ \\
\cline { 1 - 5 } Male & 108.3333 & 17.96658 & \multirow{2}{*}{0.010967} & Not Significant & $\mathrm{p}<0.05$ \\
\cline { 1 - 5 } & 102.2573 & 15.58465 & & \\
\hline
\end{tabular}

The table -1 reveals that the Mean of male students is 108.33 and that of female students is 102.25 . The SDs for the same groups is 17.96 and 15.58 respectively. The t-value is found to be 0.01 which is not significant at 0.05 levels. Hence, the null hypothesis is accepted - that there is no significant difference between male and female of higher secondary school students in their preferred learning styles. However, from Mean values, it is concluded that male students have more preferred learning styles than female students.

Table - 2: There is no significant difference between preferred learning styles with respect to government and private higher secondary school students.

\begin{tabular}{|l|l|l|l|l|l|}
\hline & Mean & SD & t-value & Result & $\begin{array}{l}\text { Level of } \\
\text { Significance }\end{array}$ \\
\hline Government & 100.55 & 15.84 & 0.0029 & Not Significant & $\mathrm{p}<0.05$ \\
\hline Private & 106.89 & 16.50 & & \\
\hline
\end{tabular}

The table -2 reveals that the Mean of government higher secondary students is 100.55 and that of private higher secondary students is 106.89 . The SDs for the same groups is 15.84 and 16.50 respectively. The $\mathrm{t}$-value is found to be 0.002 which is not significant at 0.05 levels. Hence the null hypothesis is accepted - that there is no significant difference between government and private higher secondary school students in their preferred learning styles. However, from Mean values, it is concluded that private school students have more preferred learning styles than government school students.

Table - 3: There is no significant difference between preferred learning styles with respect to rural and urban higher secondary school students.

\begin{tabular}{|l|l|l|l|l|l|}
\hline & Mean & SD & t-value & Result & $\begin{array}{l}\text { Level of } \\
\text { Significance }\end{array}$ \\
\hline Rural & 102.4444 & 16.6528 & \multirow{2}{*}{0.247429} & Not Significant & $\mathrm{p}<0.05$ \\
\hline Urban & 104.3574 & 16.3574 & & \\
\hline
\end{tabular}




\section{International Advanced Research Journal in Science, Engineering and Technology \\ Impact Factor 7.105 ㄷ Vol. 9, Issue 1, January 2022 \\ DOI: $10.17148 / I A R J S E T .2022 .9153$}

The table -3 reveals that the Mean of rural students is 102.44 and that of urban students is 104.35 . The SDs for the same groups is 16.65 and 16.35 respectively. The t-value is found to be 0.24 which is not significant at 0.05 levels. Hence, the null hypothesis is accepted- that there is no significant difference between rural and urban students of higher secondary school in their preferred learning styles. However, from Mean values, it is concluded that urban students have more preferred learning styles than rural students.

Table - 4: There is no significant difference between preferred learning styles with respect to hosteller and day scholar higher secondary school students.

\begin{tabular}{|l|l|l|l|l|l|}
\hline & Mean & SD & t-value & Result & $\begin{array}{l}\text { Level } \\
\text { Significance }\end{array}$ \\
\cline { 1 - 3 } Hostellers & 100.3465 & 26.47904 & \multirow{2}{*}{0.943506} & Not Significant & $\mathrm{p}<0.05$ \\
\hline Day Scholars & 100.5455 & 15.84162 & & \\
\hline
\end{tabular}

The table - 4 reveals that the Mean of hostellers is 100.34 and that of day scholars is 100.54 . The SDs for the same groups is 26.47 and 15.84 respectively. The t-value is found to be 0.94 which is not significant at 0.05 levels. Hence, the null hypothesis is accepted - that there is no significant difference between hostellers and day scholars of higher secondary school students in their preferred learning styles. However, from Mean values, it is concluded that hostellers have more preferred learning styles than the day scholars.

\section{RESULT AND FINDINGS}

1. There is no significant difference between male and female of higher secondary school students in their learning styles.

2. That there is no significant difference between government and private higher secondary school students in their learning styles.

3. That there is no significant difference between rural and urban higher secondary school students in their learning styles.

4. That there is no significant difference between day scholar and hosteller higher secondary school students in their learning styles.

\section{SUGGESTIONS AND EDUCATIONAL IMPLICATIONS}

The researcher, on the basis of results suggests that schools should conduct learning styles education programme to prepare students for future. The curriculum of the school needs to be revised for high learning achievement. The teacher and teacher educators need training on this regard to help the students for best learning. Teachers may be able to help students by preparing their lessons based on individual differences in learning styles and providing them better instructions to meet the challenges and demands of the world. Parents also may be helped to take care of their children they will be able to provide them more facilities, books and other materials for more learning.

The present study was limited to the higher secondary school students. The research can be extended to study primary school children, adolescence, prospective teachers, learning styles with academic achievement, academic anxiety, attitude of teacher and students towards learning styles education in the schools.

\section{CONCLUSION}

From the above results it can be concluded that there is no significant differences in the learning styles of higher secondary school students on the basis of gender, types of school, habitation and residence. The higher secondary school students were found similar in their learning styles. Hence, it is stated that learning style is important for the students, policy makers, administrators, curriculum makers, parents and teachers to help the students to explore their potentials in excelling in their academics and every field of life.

\section{REFERENCES}

Akhtar, Z. (2011). Gender-wise and Institution-wise Difference in Learning Styles of Secondary School Students. Language in India Strength for Today and Bright Hope for Tomorrow, 11, 408-418. Retrieved from https://www.researchgate.net/publi-cation/231582201_Gender-Wise_and_Institution_Wise_Difference_in_Learning _Styles_of_Secondary_School_Students on 22/10/2017. 


\section{International Advanced Research Journal in Science, Engineering and Technology \\ Impact Factor $7.105 \div$ Vol. 9, Issue 1, January 2022 \\ DOI: 10.17148/IARJSET.2022.9153}

Anand, R. S. \& Prasad, M. R. (2016) A Study on Learning Styles and Their Impact of Science Teaching Among Primary School Students. International Education and Research Journal, Vol.2(1), pp.50-52. Retrieved from http://ierj.in/journal/index.php/ierj/articles/view/101/91, dated 29.11.2020.

Bayrak, B. K. (2017) A study on learning styles of according to gender and class level. Procedia - Social and Behavioral Sciences, vol. 46 (2012), pp.843 - 847. Retrieved from www.sciencedirect.com, dated 29.11.2020.

Bhagat, A., Vyas, R. and Singh, T. (2015) Students awareness of learning styles and their perceptions to a mixed method approach for learning. International Journal Applied Basic Medical Research, 5(Suppl 1): S58-S65. Retrieved from https://www.ncbi.nlm.nih.gov /

pubmed/26380214 on 5/10/2017.

Bhat, M. A. \& Govil, P. (2014). Understanding Learning Styles of Secondary School Students in Relation to Certain Variables. Asian Journal of Multi disciplinary Studies, Volume 2, Issue 11, pp 1-8. Retrieved from https://www.researchgate.net/publication/267640163_

Understanding_Learning_Styles_of_Secondary_School_Students_in_Relation_to_Certain_Variables on 10/8/2017.

Chianson, M. M. and et.al. (2015) Prevalent Learning Style among Secondary School Mathematics Students and Its Influence on Gender and Age in Benue State, Nigeria. British Journal of Applied Science \& Technology, vol. 8(4), pp.389-399. Retrieved from https://www.journalcjast.com/index.php/CJAST/article

/download/7747/13804, dated 30.11.2020.

Gopalakrishnan, \& Palanivelu (2018) Effectiveness of Learning Styles and Academic Achievements among Secondary School Students in Mathematics Subject. International Journal of Science and Research (IJSR), Vol. 7(4), pp.10301032. Retrieved from https://www.ijsr.net/archive/v7i4/ART20181785.pdf, dated 30.11.2020.

Kalantari, and et.al. (2016) A Study of Innovation in Learning Styles of Students in Different Secondary School Branches. Journal of Psychology \& Psychotherapy, vol. 6(4), pp.1-6. Retrieved from https://www.longdom.org/openaccess/study-of-innovation-in-learning-styles-of-students-in-different-secondaryschool-branches-2161-0487-

1000274.pdf, dated 30.11.2020.

Kharb, P. et.al. (2013). The Learning Styles and the Preferred Teaching-Learning Strategies of First Year Medical Students. Journal of Clinical and Diagnostic Research: JCDR, 7(6), 1089-1092. http://doi.org/10.7860/JCDR/2013/5809.3090 on 22/10/17.

Kinjari, K and C.N. Ram Gopal, Learning style preference among adolescent school studnts. International Journal of Indian Psychology, 8(1), 944-955, DIP: 18.01.118/20200801,DOI:10.25215/0801.118. Retrieved from https://ijip.in/articles

/learning-style-preference-among-adolescent-schoolstudents/\#: :text=It $\% 20 \mathrm{was} \% 20$

found $\% 20$ that $\% 20$ based,Visual\%20and\%20Auditory\%20learning\%20style on 8.12.2021.

Mallick, S. K., De, K. K. and Mukhopadhyay, R. (2016) Learning style of secondary school students: A study. International Journal of Advanced Education and Research Vol.1(12), pp.15-20. Retrieved from /http://www.alleducationjournal.com/download/164/1-11-17-540.pdf, dated 29.11.2020.

Mehraj, A. \& Bhat, M. (2014) The Effect of Learning Styles on Problem Solving Ability among High School Students. International Journal Advances in Social Science and Humanities, ISSN: 2347-7474. Retrieved from https://www.researchgate.net/publication/264665447

_The_Effect_of_Learning_Styles_on_Problem_Solving_Ability_among_High_School_Students on 15/9/2017.

Ravi, R. \& Manju, S. (2013) Learning Styles of Primary Students: Does School Environment Intervene Learning Style? BRICS Journal of Educational Research, Vol. 3, Issue 2, pp 79-84. Published by Maharishi Markandeshwar University, Maullana - Ambala (India)

Singh, L. et.al. (2015) Learning Style Preferences Among Secondary School Students. International Journal of Recent Scientific Research Research, Vol. 6, Issue, 5, pp.3924-3928. Retrieved from http://www.recentscientific.com/sites/default/files/2411.pdf on 10.8.2017.

Singh, et.al. (2015) Learning Style Preferences Among Secondary School Students. International Journal of Recent Scientific Research, Vol. 6(5), pp.3924-3928. Retrieved from https://www.researchgate.net/profile_Laxman_Singh13/publication/324861241_LEARNING_STYLE_PREFERENCE S_AMONG_SECONDARY_SCHOOL_STUDENTS/links/5ae80f6445851588dd7f97f9/LEARNING-STYLE-

PREFERENCES-.pdf?origin=publication_detail, dated 29.11.2020.

Vaishnav, R. S. (2013) Learning Style and Academic Achievement of Secondary School Students. Voice of Research, vol. 1(4), pp.1-4. Retrieved from chromeextension://gphandlahdpffmccakmbngmbjnjiiahp/http://www.voiceofresearch.org/Doc/Mar-2013/Mar-2013_1.pdf, dated 3.12.2020. 